\title{
On China's Experience in Fighting Against COVID-19 Pandemic
}

\author{
Sisi Yan* \\ College of Marxism, Zaozhuang University, Zaozhuang, Shandong Province, China \\ *Corresponding author. Email: 1576213455@qq.com
}

\begin{abstract}
COVID-19 pandemic has been an unprecedented major public health emergency in China in the past 70 years since the People's Republic of China was founded. In the face of the sudden outbreaks, the CPC Central Committee with Comrade Xi Jinping at its core implemented targeted responses, and the broad masses of the people cooperated to the greatest extent, making China achieve a phased victory in epidemic prevention and control in a relatively short period of time. In this great anti-epidemic battle, China has strengthened its appeal with its institutional advantages, enhanced its cohesion with its mass line, and increased its inspiration by virtue of its anti-epidemic spirit. It is precisely these anti-epidemic experiences with Chinese characteristics that have effectively built a solid defense line to ensure people's life safety, and made China's anti-epidemic work enter a new stage of "normalized epidemic prevention and control".
\end{abstract}

Keywords: COVID-19 Pandemic, Institutional advantages, Mass line, Spiritual power.

\section{INTRODUCTION}

At present, the COVID-19 pandemic has become a global challenge along with its multi-point outbreak and continuous spread worldwide. It not only has been a public health emergency with the fastest spread, largest infectious coverage, and the most difficult prevention and control in the past 70 years since the founding of People's Republic of China, but also is a severe social crisis China is faced with. As General Secretary Xi Jinping said, at present and in the coming period, China's development will enter a period in which all kinds of risks and challenges will be accumulated and even exposed intensively, and the major struggles we are facing will not decrease and are getting more and more complicated. Such risks and challenges not only come from economic, political and cultural fields, but also come from nature. China's current ongoing struggle against "COVID-19 Pandemic" is undoubtedly a great one with new characteristics of the times. In the process of the fight against COVID-19 Pandemic entering a new stage of "normalized epidemic prevention and control", we have seen the strong appeal that the system of socialism with Chinese characteristics shows, realized the high cohesion on the mass line, and understood the great inspiration from the anti-epidemic spirit.
Undoubtedly, these three "golden keys" are magic weapons with Chinese characteristics, which not only build a strong defense line to protect people's lives, but also will certainly provide strong support for us to win the battle of epidemic prevention and control.

\section{CLARIFYING INSTITUTIONAL ADVANTAGES TO ENHANCE THE ANTI-EPIDEMIC APPEAL}

At the Fourth Plenary Session of the $19^{\text {th }}$ Central Committee of the Communist Party of China (CPC), it was pointed out that we should uphold and improve the system of socialism with Chinese characteristics, advance the modernization of China's system and capacity for governance, and at the same time, we should uphold the centralized and unified leadership of the CPC and encourage initiative from all sectors with concentrated efforts for big and key projects, all for the purpose of achieving fundamental goals for national development. At present, COVID-19 pandemic has close relationship with people's health, economic development and social stability, which requires good performance of the institutional efficiency and power of our country. The effectiveness of the fight against COVID-19 Pandemic is not only a concentrated test for China's system and capacity for governance, but also an 
effective demonstration for China's institutional advantages.

\subsection{The Centralized and Unified Leadership of the CPC is the Fundamental Guarantee for the Fight in Epidemic Prevention and Control}

General Secretary Xi Jinping said, "The most essential feature of socialism with Chinese characteristics is the leadership of the CPC, the greatest advantage of the system of socialism with Chinese characteristics is the leadership of the CPC, and CPC is the most powerful political leading force." [1]Upholding the centralized and unified leadership of the CPC is not only the fundamental experience for our successful reform and opening up, but also the essential force to achieve the great leap for the Chinese to become strong after standing up and becoming rich. After the outbreak of COVID-19 Pandemic, the CPC Central Committee with Comrade Xi Jinping at its core has attached great importance to the crisis, and quickly launched the blocking action, prevention and control war, and people'sfight against COVID-19 Pandemic in epidemic prevention and control by adhering to the principles of national mobilization, joint prevention and control, and openness and transparency.

This epidemic prevention and control, from the central to the local, from the group to the individual, is not only a major test for the leadership ranks of various units in various regions of China, but also an examination room for $\mathrm{CPC}$ members and cadres to practice their original aspiration and mission, and what is more, a touchstone to reflect the vanguard and exemplary role of CPC members. After the outbreak, General Secretary Xi Jinping has always learnt the epidemic progress immediately, and has held several meetings to listen to the opinions and issued a series of important speech and made a series of major instructions and comments on epidemic prevention and control. Besides, based on the overall situation and overall control, he has went deep into the anti-epidemic front line to carry out investigation and research, and personally deploy, direct and mobilize from multiple levels. Meanwhile, Party committees, governments and relevant departments at all levels have taken active actions to quickly formulate detailed plans for epidemic prevention and control, timely launch the Level I response to major public health emergencies, and form leading groups led by the main responsible comrades in various regions. Leading officials at all levels have always stood fast at their posts and commanded at forefront, and resolutely curbed the epidemic spread. All grass-roots party organizations have acted with great vigor to actively implement various epidemic prevention and control measures, and have established various forms of epidemic prevention and control vanguard teams, logistics support teams and love teams. Each
Party branch has become a battle fortress with the Party flag flying high, and every Party member mass is the front line soldier at anti-epidemic front line. It is thus clear that, after the clarion call of epidemic prevention and control was sounded, from the leadership of the CPC Central Committee to the ordinary members of the Party, each of us has been in a race with time, fighting with the illness, and jointly practicing the principles of "being clear about, performing and earnestly fulfilling responsibilities". The effectiveness of anti-epidemic measures once again shows that the CPC is leading the people of the whole country and supporting the fight for epidemic prevention and control. Only by continuing to play the leading core role of the CPC in overall planning and in coordinating all parties, can we ensure that China's anti-epidemic fight will always advance steadily in the right direction to completely stop the spread of the epidemic.

\subsection{Concentrating on Major Events Is the Institutional Advantage in Fighting the Crucial Battle of Epidemic Prevention and Control}

Comrade Deng Xiaoping once said that, compared with capitalism, socialism could be able to ensure the coordinated national response and concentrate its strength to ensure the key points, which is its superiority. [2] General Secretary Xi Jinping also emphasized that our essential advantage is that our socialist system can achieve concentration on key projects, which is an important magic weapon for our development. It has been over 70 years since the People's Republic of China was founded. It is precisely because under the leadership of the CPC that we have always adhered to concentrating our efforts on major events and mobilizing the enthusiasm of all parties. Only in this way can our country successfully overcome the earthquake, trade friction and many other risks, carry out all kinds of work in a unified and effective way, achieve various undertakings such as 'atomic bomb, hydrogen bomb and artificial satellite', and promote the steady improvement of comprehensive national strength and international influence.

Since the outbreak of the epidemic, unifiedly led, commanded and dispatched by the CPC Central Committee, we have been upholding the coordinated national response in the prevention and control for the epidemic and focusing on the core goal of stopping the epidemic, we have constantly poured the main manpower, material and financial resources throughout the country to Hubei Province, Wuhan and other severely affected areas. After the CPC Central Committee issued the call of "having one province counterpart assist one severely affected city", more than 380 medical teams formed by over 40,000 medical personnel from 29 provinces and cities went to Wuhan immediately to support the fight against the epidemic. A 
large number of daily necessities, medical treatment and protection resources were gathered to the front line of epidemic prevention and control to the maximum extent to first meet the needs of front-line medical staff and infected patients. [3] Huoshenshan (Fire God Mountain) Hospital, Leishenshan (Thunder God Mountain) Hospital and shelter hospitals have been built and put into use within shorter time. Behind China's high speed and powerful strength, it is precisely because of institutional advantage of adherence to coordinated national response and reasonable overall planning for overall situation and key points that the resultant force of concentrating on major events can be formed, so that the measures against the epidemic can be refined, and all kinds of social resources can be united in the fastest and most effective way to fully represent the efficiency of social resources, and finally, the spread of local epidemic in Wuhan can be basically blocked.

\section{ADHERING TO THE MASS LINE TO ENHANCE THE ANTI-EPIDEMIC COHESION}

At the Fourth Plenary Session of the 19th Central Committee of the Communist Party of China (CPC), it was stressed that China's national system and national governance system have obvious advantages in many aspects, including not only the obvious advantages of adhering to the people's ownership of the country, developing democracy among people, keeping close relationships with the masses, and relying on the people to promote national development, but also the obvious advantages of adhering to the people-oriented development idea, constantly securing and promoting people's livelihood, enhancing people's well-beings and striving for common prosperity. [4] Inthe new era of the system of socialism with Chinese characteristics, the people-oriented development idea is not only a clear answer from the CPC Central Committee with Comrade $\mathrm{Xi}$ Jinping at its core to the question of Working for Who and Relying on Who, but also the concentration, inheritance and sublimation for the mass line and mass viewpoint of doing everything for the masses, relying on them in every task, and coming from the masses and walking towards the masses", [5] What is more, it not only adheres to the scientificity and truth of Marxist historical view of the mass, but also shows the original aspiration and mission of the Chinese Communists.

\subsection{Relying on the Masses Is the Hard Core Power in Fighting the Crucial Battle of Epidemic Prevention and Control}

Historical events are created by the masses, so it is "masses in action" that determine the development of history. [6] The COVID-19 pandemic broke out at the beginning of this year, with wide coverage to directly relate to every Chinese people, and serious harmfulness to directly shock the soul of people who fear life. At the critical juncture that seriously threatens people's life and health and profoundly affects people's production mode and life style, national mobilization from the leadership to the masses was launched and a people's war for epidemic prevention and control was quickly started. As General Secretary Xi Jinping said, "Peoplewho create the history are the real heroesas well as the sources of our strength.'[7] It is because of relying on, mobilizing and uniting the masses that China has won the phased victory in this society-wide people's war of epidemic prevention and control in a short period of time.

The battle of epidemic prevention and control is a complex and systematic project, so, at the beginning of the epidemic, we have established a comprehensive society-wide epidemic prevention system characterized by joint prevention and control, with all from Central Committee to local governments, from communities to individuals involved in such battle. Since the epidemic, commanded by the CPC Central Committee, relying on the people of the whole country, we have mobilized the enthusiasm and creativity of the people to the greatest extent, formed strong social cohesion, and quickly built a stringent defense line for epidemic prevention and control. On the one hand, while novel coronavirus was raging, 1.4 billion Chinese people actively responded to the call of the state by consciously staying at home, voluntarily abandoning visiting relatives and friends during the Spring Festival, and voluntarily refusing to participate in various parties to isolate the virus in a way that seems to put society on hold. In particular, the people of Wuhan have made the overall situation in mind, braved all difficulties and dangers, and have been indomitable. They have consciously complied with the overall needs of epidemic prevention and control and taken the initiative to fight against the epidemic. [8] Moreover, in this grim struggle, the people, with their good hygiene habits, scientific lifestyle and healthy psychological quality, have accumulated a good atmosphere of scientific prevention and control, no belief in and no spreading of rumors and strong positive energy of anti-epidemic in the whole society. On the other hand, in order to effectively respond to the epidemic, the governments, enterprises, communities, towns and hospitals have performed their respective responsibilities and coordinated effectively. The CPC Central Committee's decisions have been quickly and effectively delivered to thousands of villages from the Central Committee; many enterprises took the initiative to refit their workshop equipment to produce masks and medicines urgently needed for anti-epidemic; medical staff volunteered to participate in this battle; many unknown and most beautiful countermarching people emerged in logistics, transportation, express delivery, publicity, epidemic prevention screening and other fields; love donation were more active. It is the broad participation and full cooperation of the people all over 
the country that has formed an important force in the fight against the epidemic, strengthened the responsibility for prevention and control for the epidemic and built a community of shared future, to prevent the virus from spreading to the greatest extent.

\section{2. "Doing Everything for the Masses" is the Value Standpoint of Fighting the Battle of Epidemic Prevention and Control}

All the movements in the past were for the minority or for the benefit of the minority. The proletarian movement is independent movement of the immense majority and for the benefit of the overwhelming majority. [9] As a Marxist party, the CPC has clearly written "Seeking Happiness for People" on its banner at the beginning of its establishment. The affinity to the masses is the most distinctive character of Marxism. The masses' standpoint is the fundamental political stand of Marxism, and also the fundamental stand of Xi Jinping Thought on Socialism with Chinese Characteristics for a New Era. Faced with the threatening COVID-19 pandemic, General Secretary Xi Jinping has repeatedly highlighted an important principle on different occasions, i.e. taking people's safety and health as the top priority. [10] The concept of "life first, people first" has been demonstrated incisively and vividly in the whole anti-epidemic process in China, which is not only an answer to the original inspiration of the Chinese communists, but also a response to their mission.

Since the outbreak of the epidemic, "proceeding from the interests of the people and doing everything is for the masses" has become the fundamental value of the fight against the epidemic. "Doing everything is for the masses" first embodied in respecting for the lives of infected patients. We will never give up any life, and as long as there is a slim hope, we will make a 100 percent effort. [11] No matter the patient is an infant or a pregnant woman, the elderly or the disabled, we will always try our best to save every one of them. In order to save lives and meet the needs of COVID-19 patients, China has made every effort to smooth the "green channel" for saving lives: at all costs, purchase and recruit a large number of "life-saving artifacts" for critically ill patients; cover all expenses incurred during the treatment of patients by financial subsidy, regardless of the cost. In addition, "doing everything for the people" is also reflected in the concern and guarantee for the people's livelihood. To meet the basic living requirements of the masses, the $\mathrm{CPC}$ and the government have actively organized the production, distribution and supply of relevant living materials; to implement the supervision power by the people and to enhance their confidence in fighting the epidemic, the CPC and the government have been doing a good job in the publicity on the progress of the epidemic situation and guidance of public opinions; to help small and medium-sized enterprises tide over the difficulties, the $\mathrm{CPC}$ and the government have timely made the correct decision-making for the orderly resumption of work and production. It is precisely because of following the people-centered anti-epidemic concept that the vast majority of provinces in China have made significant achievements in "double zero" for confirmed cases and new cases.

\section{CARRYING FORWARD THE SPIRITUAL POWER TO ENHANCE THE INSPIRATION OF ANTI-EPIDEMIC}

The power of spirit is infinite. Man must have a noble thought, [12] and a country and a nation more need to be spiritually powerful. During the hard struggle of the Chinese, the spirit of China has always promoted the Chinese to move forward and develop. Whenever we are faced with some critical moments, or experience some major events, there will always be a noble and great spirit to be bred and born. In the process of uniting our whole nation to fight against the epidemic, the great "anti-epidemic spirit" emerged as the times require. As a unique symbol of the times of the Chinese nation, such spirit not only enhances the inspiration of anti-epidemic for winning the battle of the epidemic prevention and control, but also becomes an important part of the Chinese spirit because of its profound connotation of the times.

At the beginning of the fight against COVID-19 pandemic, focusing on the general trend of epidemic prevention and control, General Secretary Xi Jinping has raised the general working policies of strengthening confidence, working together and taking science-based and targeted measures,[13] while carrying out investigation and guidance on epidemic prevention and control in Beijing, General Secretary Xi Jinping also pointedly emphasized the four spirits, namely, "the spirit of enduring hardships and fighting", "the fearless revolutionary spirit of moving forward in the face of hardships", "the great love spirit of supporting from all sides if one side is in trouble" and "the noble spirit of treating patients with benevolence" , [14] besides, people from all ethnic groups in China have taken actions against the epidemic. All of these vividly explain the rich connotation of the great anti-epidemic spirit, which internally contains the core essences of "life first, unity of the nation, selflessness, respect for science, and common destiny". From a deeper level, this anti-epidemic spirit not only inherits the excellent traditional spirit of the Chinese nation, but also highly recognizes the current anti-epidemic practice of the Chinese people. Under the particular background of the time with the COVID-19 pandemic raging, no matter the anti-epidemic vanguard with touching deeds or the ordinary volunteers who contribute silently, each of them depicts a patriotic anti-epidemic history of Chinese 
people with sincere home-country feelings, and casts the Chinese spirit with the characteristics of the new era, which enriches and develops the national spirit and the spirit of the times by socialism with Chinese characteristics in the new era in response to the specific risks and challenges posed by the epidemic. This great anti-epidemic spirit will inspire the Chinese people in the new era with its strong inspiration to continue to rise up to completely defeat the illness as soon as possible!

\section{CONCLUSION}

The sudden outbreak of COVID-2019 pandemic is a serious disaster for China, but it is also the largest open experiential public class of self-confidence and system confidence in China. As General Secretary Xi Jinping said, "people are looking forward to us, history is looking forward to us, and the world is looking forward to us." [15] Led firmly by the CPC, by virtue of China's institutional advantages, the tenacious struggle of the people of the whole country and the great appeal of the anti-epidemic spirit, we have taken the most comprehensive, strict and complete measures for prevention and control to curb the spread of the epidemic, and actively cooperated internationally in epidemic prevention and control. The anti-epidemic answer sheet we handed over has already stood the test of the people, time and history. In the process of fighting against the illness, we hope and believe that China will win a great victory!

\section{REFERENCES}

[1] Guidance Readings for the Report of the 19th CPC National Congress, Beijing: People's Publishing House, 2017 Edition, P19 P20.

[2] Selected Works of Deng Xiaoping, Volume 3, People's Publishing House, 1993 Edition, P16 and P17.

[3] The Standing Committee of the Political Bureau of the CPC Central Committee Convened A Meeting to Study and Strengthen the COVID-19 Prevention and Control Work [N]. People's Daily, Feb. 4, 2020.

[4] Decision of the CPC Central Committee on Upholding and Improving the System of Socialism with Chinese Characteristics and Promoting the Modernization of National System and Capacity for governance, People's Daily, Nov. 6, 2019.

[5] Selected and Edited Important Documents Since the Third Plenary Session of the CPC Central Committee, Vol. 2, People's Publishing House, 1982 Edition, P834.

[6] Complete Works of Marx and Engels (Volume 2) [M]. Beijing: People's Publishing House, 1957.

[7] Xi Jinping. People's Yearning for a Better Life is Our Goal of Struggle [N]. People's Daily, Nov. 16, 2012.

[8]http://guancha.gmw.cn/2020-03/11/content_3363931 7.htm

[9] Marx and Engels: Manifesto of the Communist Party, People's Publishing House, 2018 Edition, P39.

[10] https://www.sohu.com/a/370388719_100009880

[11]http://www.xinhuanet.com/politics/2020-05/23/c_11 26024169.htm

[12] Mao Zedong: Selected Works of Mao Zedong, People's Publishing House, 1991 Edition, P660.

[13]http://www.qstheory.cn/2020-02/21/c_1125606422. htm

[14] https://www.sohu.com/a/372466006_120044381

[15] Xi Jinping. Xi Jinping's Speech at the National People's Political Consultative Conference New Year Tea Party [N]. People's Daily, Jan. 1, 2016 (2). 